\title{
Gerakan Feminisme Jepang Studi tentang Gerakan Protes Ketidakadilan terhadap Perempuan pada Awal Zaman Modern
}

\author{
Endah H. Wulandari
}

\begin{abstract}
The Bunmei Kaika policy which was applied by the Meiji regime motivated a kind of feminism understanding upon grups of men and women. The understanding was followed by many individual movements that were aimed at the fighting for equality between men and women in various aspects of life. The preliminary movement that was done individually then developed towards a movement that shaped a wider social net through the establishment of women organization.
\end{abstract}

KATA KunCI Feminisme, kesadaran feninisme, gerakan perempuan.

Masa dari tahun 1868 sampai dengan menjelang Perang Dunia II dalam periodisasi sejarah Jepang dikenal sebagai periode Jepang modern, yang ditandai dengan perubahan besar-besaran di semua bidang kehidupan masyarakat. Tahun 1868 secara resmi dikenal sebagai tonggak dimulainya zaman Meiji, yang merupakan awal keterbukaan Jepang setelah sekitar 260 tahun menutup diri dari hubungan internasional. Perubahan paling utama yang dilakukan rezim Meiji adalah membuat kebijakan yang membawa perubahan dalam segala aspek kehidupan untuk meraih tujuan negara di bawah simbol-simbol Fukoku Kyohei.

Di bawah pelbagai kebijakan restorasinya, rezim Meiji ingin membawa Jepang ke era modern dengan mengubah Jepang lama yang feodal-agraris menjadi negara industri. Perkembangan perindustrian yang pesat membawa kemajuan perekonomian dan menjadi landasan bagi terbentuknya Jepang modern.

Setelah Jepang memantapkan diri sebagai "negara modern" pada paruh terakhir abad ke-19, dimulailah proses pembinaan bangsa dalam segala aspek politik, sosial ekonomi, dan budaya. Proses inilah dalam sejarah Jepang dikenal sebagai Bunmei Kaika. Dengan kebijakan ini, rezim Meiji mengadopsi peradaban Barat, yang antara lain adalah menghapuskan diskriminasi kelas yang khas masyarakat feodal.

\footnotetext{
${ }^{1}$ Terminologi ini sebenarnya merupakan aplikasi dari pemikiran keimou shishou
} 
Hasil Bunmei Kaikn yang direalisasikan dalam bidang pendidikan serta pemikiran tokoh-tokoh intelektual seperti Fukuzawa Yukichi dan Mori Arinori memungkinkan munculnya tokoh-tokoh intelektual perempuan, antara lain Tsuda Umeko, Kishida Toshiko, Fukuda Hideko, Hiratsuka Raicho dan sebagainya. Para intelektual perempuan itu tergerak untuk memperjuangkan kaum perempuan yang tertindas hak-hak dasarnya sebagai manusia. Mereka berusaha mengatasinya. Namun, dalam tahap awal mereka belum membentuk suatu jaringan gerakan sosial yang sambung-menyambung. Mereka masing-masing bekerja dalam lingkup yang terbatas. Secara perlahan-lahan kesadaran yang bersifat individual mengalami kematangan dan mengkristal dalam bentuk kesadaran kelompok. Munculnya pelbagai organisasi perempuan yang memperjuangkan hak-hak kelompok menjadi salah satu bukti nyata. Dalam proses perubahan itu, gerakan individual menjadi suatu gerakan kelompok ini dapat disebut sebagai gerakan feminis.

\section{FEMINISME}

Istilah feminisme yang sering dipandang dengan sinis sebenarnya berasal dari kata latin femina yang berarti 'memiliki sifat keperempuanan' (Hubies 1977: 19). Di dalam Kamus Besar Bahasa Indonesia (KBBI), feminisme diartikan sebagai 'gerakan wanita yang menuntut persamaan hak sepenuhnya antara kaum wanita dan pria'. Istilah feminisme merupakan penggabungan pelbagai doktrin hak-hak yang sama bagi perempuan. Feminisme diawali oleh ketimpangan relasi antara laki-laki dan perempuan di masyarakat sehingga pada akhirnya timbul kesadaran dan upaya untuk menghilangkan ketidaksetaraan dalam relasi ini.

Istilah feminisme sering disalahpahami. Padahal, yang dimaksud dengan istilah tersebut mengacu pada gerakan sosial (social movement) yang dilakukan baik oleh kaum perempuan maupun kaum laki-laki untuk meningkatkan kedudukan dan peran kaum perempuan serta memperjuangkan hak-haknya secara lebih adil. ${ }^{2}$ Makna konsep feminisme yang digunakan dalam tulisan ini disesuaikan dengan dengan arti yang dimaksud oleh si pemakai pada masanya karena setiap periode mengandung arti yang berbeda. Pendapat lain yang menarik dikemukakan oleh Ciciek Farha. Menurut Farha (2000: 69), yang dimaksud dengan istilah feminisme adalah 'sebuah kesadaran akan adanya ketertindasan perempuan baik di lingkup rumah tangga, di tempat kerja, ataupun di tengah masyarakat dan berdasarkan kesadaran itu diupayakan pelbagai cara untuk mengatasi masalah tersebut'. Dengan demikian, kalau kita berpegang pada definisi itu, siapa pun dia, baik laki-laki maupun perempuan, jika sadar akan ketimpangan relasi sosial yang merugikan salah satu pihak, dan berusaha untuk menghapuskan keadaan yang demikian, orang itu dapat digolongkan sebagai kaum feminis.

\footnotetext{
${ }^{2}$ Terdapat pelbagai ragam dan definisi yang berkenaan dengan istilah feminisme yang dikemukakan oleh pelbagai kalangan, baik akademisi, praktisi, maupun aktivis.
} 
Pemetaan konvensional tentang faksi-faksi yang ada di dalam feminisme saat ini kiranya dapat membantu untuk melihat sampai sejauh mana pergulatan "isme" ini dalam menghadapi dinamika sejarah kemanusiaan dewasa ini. Pada umumnya gerakan feminisme dapat dibagi menjadi beberapa golongan, yakni feminisme liberal, feminisme sosialis, feminisme radikal, dan feminisme teologi (Sumiarni 2004: 60-88), feminisme marxis, feminisme sosialis, feminisme liberal, feminisme radikal (Farha 2000: 70). Amal (1995: 85) menambahkannya dengan feminisme psikoanalisa dan feminisme eksistensialis. Masing-masing memiliki kerangka ideologi dengan target dan pencapaian tujuan yang berbeda-beda dan seringkali tumpang tindih. Untuk mempersingkat bahasan, dalam tulisan ini tidak akan dibahas lebih lanjut pemetaan feminisme.

Tulisan yang merupakan hasil penelitian awal ini merupakan telaah bagaimana kebijakan Bunmei Kaika 'sipilisasi' yang diterapkan rezim Meiji mencetuskan semacam "kesadaran feminis" di kalangan intelektual, baik kaum laki-laki maupun perempuan. Untuk mencapai tujuan itu digunakan penelitian kepustakaan dengan metode deskripsi analisis. Pendekatan penelitian dilakukan melalui pendekatan ilmu sejarah, terutama sejarah sosial dengan kaum perempuan sebagai fokusnya. Sejarah yang ditelaah terutama berpumpun pada periode modern. Berdasarkan fakta-fakta yang ditemukan dalam penelitian ini, terdapat beberapa hal yang penting dicermati lebih lanjut, terutama pendidikan yang berkaitan dengan munculnya "kesadaran feminis".

Gerakan feminisme baru muncul seiring dengan ideologi aufklarung yang muncul di Eropa pada abad ke-15-18, yang ditandai dengan pemujaan rasio sebagai gagasan dominannya dan tergambarkan dalam ungkapan Rene Descrates, "Saya berpikir maka saya ada". Pendek kata, dari rasionalisme muncul pemikiran bahwa manusia, baik laki-laki maupun perempuan, adalah mahkluk rasional. Pada akhirnya rasionalisme mempengaruhi revolusi Prancis (1789-1793). Dengan menggunakan slogan liberte, equalite, dan fraternite, rakyat Prancis berhasil meruntuhkan rezim kerajaan yang otoriter dan menggantikannya dengan kekuasaan republik yang diharapkan lebih demokratis. Namun, kondisi demikian tidak dengan serta-merta membuat kaum perempuan dapat menikmati hasil perjuangannya menumbangkan rezim kerajaan yang otoriter. Beberapa pembatasan dan peraturan yang dikeluarkan pemerintah republikan justru banyak merugikan hak-hak kaum perempuan. Kondisi seperti itu melatarbelakangi munculnya gerakan feminisme di Prancis pada tahun 1870.

Di Jepang, gerakan semacam itu mulai tumbuh pada akhir abad ke-19. Kaum perempuan Jepang pada masa-masa sebelumnya, terutama pada masa rezim militer Tokugawa, mengalami diskriminasi dalam pelbagai tataran dengan beroperasinya pranata misoginis yang banyak ditemukan dalam kehidupan sehari-hari. Sebagai contoh adalah praktik pewarisan tunggal melalui chounan ${ }^{3}$, mekake seido ${ }^{4}$, dan adat-istiadat lain yang

\footnotetext{
${ }^{3}$ Praktik pewarisan tunggal melalui anak laki-laki pertama.

+ Sistem pergundikan yang legal, yang dilakukan untuk menjamin adanya keturunan laki-laki, namun sering berubah menjadi praktik perbudakan.
} 
dilembagakan melalui keluarga. Agama sering digunakan sebagai bungkus superioritas laki-laki. Hal ini terungkap dalam berbagai sekte Buddha yang menyatakan bahwa perempuan adalah mahkluk "penggoda" dan "penuh dosa" dan harus dilahirkan kembali sebagai laki-laki sebelum mendapat "pencerahan". Demikian pula halnya di dalam Konfusianisme yang mengandung elemen misoginis, misalnya ajaran gorin goyonya "Lima Hubungan Besar". Pranata misoginis dilandasi oleh pemahaman serta praktik yang mengunggulkan kaum lelaki dengan dengan segala maskulinitasnya.

\section{Reformasi Pendidikan}

Setelah Jepang memantapkan dirinya sebagai "negara baru" pada paruh terakhir abad ke-19, dimulailah proses pembinaan bangsa dalam segala aspek, termasuk di dalamnya adalah aspek politik, sosial, ekonomi, dan budaya. Proses inilah yang dikenal sebagai Bunmei Kaika 'sipilisasi'. Terminologi ini sebenarnya merupakan aplikasi dari pemikiran keimoshisoo 'pencerahan'.

Ketika pemerintah Meiji (1868-1912) mengadopsi kebijakan modernisasi dan mulai memperkenalkan peradaban Barat ke Jepang, para intelektual Keimoo yang terkenal, seperti Fukuzawa Yukichi, Mori Arinori, Nishi Amane, dan Tsuda Mamichi, banyak mengisi pemikiran intelektualnya dalam artikel-artikel di majalah Meiroku Zasshi, majalah yang diterbitkan oleh kelompok intelektual Meirokusha "Perhimpunan Tahun ke-6 Meiji". Di antara para intelektual tersebut, Mori, selain aktif dalam bidang pendidikan, juga menulis buku Saishooron, yang menyorot tentang masalah emansipasi para istri dan masalah pergundikan.

Dengan kebijakan yang disebut Bunmei Kaika, pemerintah Meiji mengadopsi kebijakan modernisasi dan mulai memperkenalkan peradaban Barat, antara lain adalah menghapuskan diskriminasi kelas yang khas masyarakat feodal. Bunmei Kaika direalisasikan antara lain dalam sistem pendidikan baru. Untuk mempersiapkan sistem itu, pada tahun 1872 pemerintah Meiji mengirimkan utusan ke Eropa dan Amerika yang dipimpin oleh Iwakura Tomomi untuk mencari suatu sistem pendidikan yang cocok. Ikut dalam misi ini lima orang gadis yang berusia 9-16 tahun, yaitu Nagai Shige, Yamakawa Sutematsu, Yoshimasu Ryo, Ueda Tei, dan Tsuda Umeko.

Pada masa sebelumnya pendidikan hanya diperuntukan bagi anak lakilaki, baik bagi anak pejabat tinggi di sekolah-sekolah yang didirikan oleh para daimyo di wilayah kekuasaannya masing-masing maupun bagi anak kebanyakan di Terakoya. Pada bulan September 1872 pemerintah Meiji memberlakukan sistem pendidikan baru yang disebut Gakusei. Dengan sistem pendidikan baru, pemerintah Meiji memberikan kesempatan kepada kaum wanita untuk mengembangkan diri secara terbatas. Gakusei bersendikan pada tiga hal, yaitu penghapusan kebiasaan lama bahwa anak wanita tidak berpendidikan, penghapusan perbedaan dalam pendidikan antara laki-laki dan wanita, dan penghapusan perbedaan dalam moral 
manusia. Walaupun ditetapkan oleh kementerian pendidikan Jepang pada waktu itu, sistem Gakusei tidak bisa dilepaskan dari pengaruh perjuangan Fǔkuzawa Yukichi (Kenkyukai 1994: 9).

Sistem Gakusei adalah sistem pendidikan formal model Barat yang bertitik berat pada Seiyoteki Kyoiku 'ilmu pengetahuan Barat'. Sistem itu meniru administrasi model Perancis, namun kurikulum pendidikannya meniru sistem Amerika. Dalam sistem tersebut, sekolah dasar yang didirikan diperuntukkan bagi seluruh anak-anak yang sudah mencapai umur 610 tahun sehingga dapat dikatakan merupakan pendidikan wajib bagi anak laki-laki dan wanita. Setelah itu, pada tahap sekolah menengah, kurikulum yang diajarkan dibedakan. Dengan demikian, dalam sistem Gakusei yang dijalankan oleh pemerintah pada waktu itu terdapat dualisme, yaitu pendidikan formal antara anak laki-laki dan wanita. Mengenal hal itu, Okamura (1980: 54) dan Yoshimi (1988: 194) mengatakan,

Sistem ganda dalam pendidikan ini telah menimbulkan banyak kemungkinan bagi pelaksanaan diskriminasi antara kaum pria dan wanita, yakni praktik yang merupakan bagian yang tak terpisahkan dalam masyarakat Jepang. Sistem diskriminasi ini berlandasan pada sebuah sikap yang teruangkapkan dalam pepatah feodal 'pendidikan tak perlu bagi kaum wanita,' yang berlanjut dalam versi yang baru yang berbunyi 'tiada memiliki pendidikan bagi kaum wanita merupakan kebaikan.

Sistem ganda yang dimaksud oleh Okamura (1980) dalam pernyataannya di atas sesuai dengan politik Bunmei Kaika yang dijalankan pemerintah, yaitu kehendak untuk mencerdaskan bangsa melalui sistem pendidikan Gakusei. Namun, di lain pihak akibat sifat dan sikap feodalisme yang terbawa oleh para elit Meiji, khususnya para pemimpin di bidang pendidikan, mereka justru menganggap bahwa pendidikan wanita tidak perlu.

Boleh dikatakan bahwa pemerintah Meiji secara sadar telah melakukan diskriminasi antara laki-laki dan wanita dalam bidang pendidikan. Isi pendidikan wanita lebih condong ke arah memberdayakan wanita ke arah kenboshugi 'ibu yang bijaksana'. Pendidikan formal bagi wanita cenderung mendidik dan membentuk moral dasar wanita dalam membina keharmonisan kehidupan keluarga. Wanita diharapkan mampu mendidik anak-anak di samping menjadi pasangan yang baik bagi suaminya. Yang dimaksud menjadi pasangan yang baik di sini adalah wanita tidak hanya menjadi pekerja yang patuh dalam kehidupan keluarga. Perempuan yang memiliki pendidikan diharapkan mampu membantu dan memberi semangat suami. (Joseishi Sogo Kenkyukai 1994: 10).

Dualisme dalam sistem pendidikan Jepang pada akhirnya menimbulkan banyak kemungkinan bagi pelaksanaan diskriminasi antara laki-laki dan wanita, yakni praktik yang telah merupakan bagian yang tidak terpisahkan dalam kehidupan masyarakat Jepang. Sistem diskriminasi ini berlandaskan pada sebuah sikap yang terưngkap di dalam pepatah feudal, yaitu pendidikan tidak perlu bagi kaum wanita, yang berlanjut dalam versi baru pada masa Meiji yang berbunyi "tiada memiliki pendidikan bagi wanita merupakan kebaikan". Gagasan tentang pendidikan bagi wanita yang demikian itu merupakan pendukung yang praktis bagi idelogi yang resmi 
yang beranggapan bahwa istri yang baik dan ibu yang bijaksana adalah mereka yang dapat menyesuaikan diri dengan kehidupan kaum pria yang secara setia dan patriotis melaksanakan tugas mereka. Kepercayaan dan tradisi masyarakat feodal yang telah berlaku pada periode sebelumnya terus berlanjut pada zaman transisi.

Menurut tradisi yang masih berlaku, kebahagiaan bagi seorang wanita adalah apabila ia dapat memajukan pendidikan di rumah tangganya, sedangkan menurut ajaran Konfusianisme, tugas wanita adalah memelihara anak. Dengan demikian, jika ditinjau baik segi agama maupun tradisi yang telah mengakar pada masa-masa sebelumnya, peranan wanita tidak mengalami perubahan. Menurut Takamure, konsep itu sebenarnya berasal konsep Barat, yaitu good wife wise mother, yang dijabarkan dalam konsep Jepang menjadi ryousaikenbo, yang kemudian diambil dan diadopsi oleh pemerintah Meiji dan ditetapkan sebagai pola ideal yang cocok diterapkan terhadap kaum perempuan Jepang saat itu.

Telah dijelaskan bahwa pengaruh pemikiran Fukuzawa sangat besar terhadap pembentukan Gakusei. Pemikiran Fukuzawa Yukichi (1835-1901) mengenai cara memajukan rakyat, khususnya tentang memberdayakan wanita, cukup berpengaruh di kalangan rakyat. Fukuzawa Yukichi, terutama seperti yang termuat sebagai pokok-pokok pendidikan baru Gakusei di dalam bukunya yang terkenal Gakumon no Susume ${ }^{5}$, antara lain mengatakan,

Langit tidak menakdirkan seseorang pada tempat di atas atau di bawah seseorang yang lain. Ini berarti bahwa kalau orang-orang dilahirkan dari langit, mereka sama derajatnya. Tidak terdapat perbedaan yang hakiki antara yang tinggi dan yang rendah... [...] Tiap-tiap manusia itu duduk sama rendah dan tegak sama tinggi. Tiap-tiap manusia mempunyai hak hidup dalam keadaan bebas dan merdeka tanpa menghiraukan perbedaan kedudukan yang timbul. [...] Hak-hak asasi manusia adalah hakikat moril yang agung yang memberikan martabat kepada kehidupan seorang manusia. [...] Pada waktu langit melahirkan manusia, kepadanya diberikan perangkat-perangkat badan pikiran dan kekuatan-kekuatan untuk menegakkan hak-haknya masing-masing. Oleh sebab itu dalam keadaan bagaimanapun juga, seseorang tidak boleh dirampas hak-haknya (Dalam Anwar 1999: 100-101).

Pokok-pokok pikiran Fukuzawa Yukichi dengan tegas mengajarkan kepada rakyat Jepang pada waktu itu bahwa semua manusia baik kaum laki-laki maupun kaum perempuan memiliki hak dan kewajiban yang sama. Dengan karya-karyanya yang lain yang banyak menyorot tentang kedudukan kaum perempuan, hak perempuan, dan pemberdayaan

\footnotetext{
${ }^{5}$ Gakumon no Susume adalah suatu buku klasik yang amat sederhana namun memiliki popularitas yang amat tinggi pada masa diterbitkannya. Baik kesederhanaan maupun popularitasnya merupakan pertanda isinya relevan dengan semangat zaman, yang semakin dirasakan dengan berlalunya waktu. Fukuzawa Yukichi mulai menulisnya pada tahun 1872 dan baru diselesaikannya pada tahun 1876, Gakumon no Susume sendiri sebenarnya merupakan antologi tulisannya. Berkat pemikirannya, Fukuzawa Yukichi dapat digolongkan sebagai tokoh cendekia yang unik dalam sejarah intelektual Jepang.
} 
perempuan, antara lain Nihon Fujin Ron 'Pembahasan mengenai Perempuan Jepang', Danjo Kosai Ron 'Teori Pergaulan antara Laki-laki dan Perempuan', dan Shinjo Daigaku 'Universitas Perempuan Baru', kiranya tidak berlebihan Fukuzawa Yukichi ditempatkan sebagai tokoh feminis Jepang. ${ }^{6}$ Dalam kehidupan pribadinya sendiri Fukuzawa Yukichi telah mendorong anak-anak perempuannya untuk mempelajari segala hal yang patut dikerjakan perempuan untuk mengelola kehidupan rumah tangga. Ia juga menganjurkan anak-anak perempuannya untuk mengabdi kepada keluarga dan menuntut ilmu ke jenjang yang lebih tinggi.

Pada tahun 1879, karena dianggap terlalu revolusioner dan tidak sesuai dengan realitas masyarakat di masa transisi pada waktu itu, dan dianggap terlalu berorientasi Barat, Gakusei dihapus dan digantikan dengan Kyoiku Rei 'Peraturan Pendidikan'. Sistem pendidikan yang termaktub di dalam sistem baru itu dapat dikatakan merupakan kombinasi daari pendidikaan timur dan Barat. Dengan adanya Kyoiku Rei, wanita terdorong untuk masuk dan belajar di sekolah sampai tingkat yang lebih tinggi. Meskipun demikian, pada dasarnya Kyoiku Rei menekankan pendidikan berdasarkan moral Konfusianis yang telah ada pada pada masa-masa sebelumnya. Dengan pendidikan model itu, diharapkan kaum perempuan bersikap "jinak" dan menjaga "keperawanan" (Joseshi Sogo Kenkyukai 1994: 55).

Selanjutnya, sistem pendidikan tersebut diperbaiki pada tahun 1880 dengan Kaisei Kyoiku Rei 'Peraturan Pendidikan yang Direvisi'. Dengan perubahan itu, masyarakat mulai merasakan manfaat pendidikan wanita. Pada tahun 1890 keluarlah Kyoiku Chokugo 'Dekrit Kekaisaran tentang Pendidikan', yang berisi tentang prinsip-prinsip pendidikan Jepang modern. Dekrit ini pada dasarnya difokuskan pada peranan pendidikan untuk kepentingan tanah air.

Secara perlahan-lahan sistem pendidikan mengalami perubahan sesuai dengan slogan yang telah dicanangkan pada awal zaman modern pemerintah Meiji yang menggunakan slogan fukoku kyohei 'negara kaya tentara kuat' demi menyetarakan diri dengan negara-negara yang lebih maju saat itu. Pemerintah menganggap perlunya partisipasi dari seluruh rakyat Jepang. Untuk anggapan itu, pemerintah membuat suatu peraturan keluarga yang menempatkan ibu dalam peranan sentral untuk mendidik dan membesarkan anak. Kebijakan pemerintah Meiji sampai pada akhir zaman Meiji berlandaskan pada gender, yaitu meletakkan wanita di dunia domestik dengan menekankan kepentingan lebih pada peran wanita sebagai ibu. Usaha pengurangan penduduk dengan keluarga berencana dan masalah-masalah lain yang dihadapi wanita tidak menjadi perhatian pemerintah. Keluarga berencana masih dilarang. Wanita masih dihargai dalam hal kemampuan produktifnya membantu suami melakukàn manajemen kehidupan rumah tangga. Dengan demikian, pemerintah pada waktu itu berkeyakinan bahwa wanita merupakan faktor utama di dalam perkembangan dan kemajuan suatu bangsa. Memasuki tahun 1888, model

${ }^{6}$ Lihat definisi feminisme menurut Farha. 
pendidikan yang berorientasi pada hal yang telah disebutkan di atas sebagai ryoosaikenbo 'istri yang baik ibu yang bijaksana'.

Logika dasar pembentukan ryoosaikenbo adalah keluarga sehingga dapat dikatakan mengulang kembali ajaran Konfusianisme masa feodal, yakni Onna Daigaku, yang antara lain mengajarkan bahwa "wanita, semasa gadis, harus patuh pada ayah; setelah menikah, harus patuh pada suami; dan setelah tua, harus patuh pada anak laki-lakinya". Artinya, tradisi lama yang mulai membedakan adanya wilayah kegiatan, yaitu wilayah publik dan wilayah domestik, dikembalikan. Wilayah publik diidentikan dengan kegiatan laki-laki, sedangkan wilayah domestik dengan kegiatan wanita sehingga wanita harus berkonsentrasi di rumah tangga. Mengutip pendapat Takamure Itsue dalam Yoshimi (1988: 204214), konsep itu sebenarnya berasal dari Barat, dan diperkenalkan oleh Hatoyama Haruko $(1861-1938)^{7}$.

\section{Muncul dan Berkembangnya Gerakan Feminisme Di Jepang}

Hasil Bunmei Kaika yang direalisasikan dalam bidang pendidikan dan sumbangan pemikiran Fukuzawa Yukichi, Mori Arinori, serta para pemikir Keimo yang lain adalah munculnya seorang tokoh wanita. Tsuda Umeko (1865-1929) merupakan gadis termuda (9 tahun) yang dikirim untuk belajar ke luar negeri bersama-sama dengan misi yang dipimpin Iwakura Tómomi. Setelah kembali dari tugas belajarnya di Amerika pada tahun 1882, Tsuda Umeko aktif berkerja di bidang pendidikan, dan pada sekitar tahun 1900-an ia mendirikan Joshi Eigaku Juku0'Sekolah Bahasa Inggris Wanita', yang kelak pada kemudian hari terkenal sebagai Kolese Tsuda. Walaupun dimulai dengan sejumlah sepuluh orang gadis saja, Kolese Tsuda memberi sumbangan besar terhadap perkembangan pendidikan tinggi bagi wanita. Di kolesenya itu, Tsuda mengajarkan pendidikan yang relatif beratmosfer modern, dengan menyiapkan murid-muridnya agar mandiri secara ekonomi dengan bekerja sebagai guru bahasa Inggris, salah satu dari beberapa bidang pekerjaan kaum wanita di luar rumah yang sudah diterima oleh masyarakat.

Tokoh wanita lain yang muncul dan berasal dari kalangan orang kebanyakan adalah Kishida Toshiko (1863-1901), yang muncul membawakan orasi dalam sebuah pertemuan politik Osaka pada tanggal 1 April 1882. Orasi yang dibawakannya dengan gaya yang memikat, yaitu Fujo no Michi 'Jalan Wanita', mengundang kekaguman hadirin yang menyesaki pertemuan tersebut. ${ }^{8}$ Isi orasinya itu mengulas kesetaraan antara laki-laki dan wanita secara argumentatif. Sejak usia 15 tahun, Kishida Toshiko tinggal di lingkungan istana kekaisaran sebagai guru sekaligus

${ }^{7}$ Hatoyama Haruko dikenal sebagai seorang pendidik yang lahir dari keluarga samurai di Matsumoto (Nagano). Setelah lulus dari Universitas Wanita Ochanomizu, ia menikah dengan Hatoyama Kazuo, seorang politisi sekaligus pengacara. Anak tertuanya, Hatoyama Ichiro, kelak dikenal sebagai Perdana Menteri Jepang. Ia juga dikenal aktif dalam organisasi Aikoku Fujinkai 'Masyarakat Wanita Patriotik'. 
dayang dari ratu Shooken (1850-1914), istri Kaisar Meiji. Namun, pada tahun 1882 Kishida keluar dari lingkungan istana dan dengan kerja sama politisi-politisi dari Jiyuu-To 'Partai Liberal' ${ }^{9}$, ia memulai turnya yang panjang ke pelbagai daerah untuk memberikan orasi. Kishida menyerukan kepada seluruh komponen bangsa, baik laki-laki maupun perempuan, untuk turut berpartisipasi aktif dalam politik. Pengalamannya tinggal di lingkungan istana yang masih konservatif memberikan kesadaran tentang nasib kaum perempuan yang terkurung di dalam rumah. Euforia semangat demokrasi membuatnya terjun langsung sebagai aktivis Jiyuu Minken Undou ${ }^{10}$, 'Gerakan Hak dan Kebebasan". Jiyuu Minken Undou menjadi sarana Kishida untuk menyalurkan aspirasi dan menjadikan pijakan bagi perjuangannya untuk mendapatkan hak rakyat, khususnya kaum wanita (Nobuhiko 1977: 92).

Dalam pidato-pidatonya yang kerap dimuat dalam koran lokal, Kishida mendorong agar kaum perempuan aktif berjuang untuk menuntut hakhaknya sebagai anggota masyarakat. Orasinya mampu membangkitkan emosi, semangat, dan kesadaran rakyat untuk meraih kebebasan dan

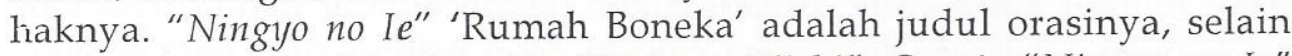
orasinya yang terkenal, yaitu "Fujo no Michi". Orasi "Ningyo no Ie" didasarkan atas pengalaman pribadinya tinggal di istana yang terkungkung dalam semangat konservatisme. Orasi lain yang juga cukup dikenal khalayak pada zamannya adalah "Hako Iri Musume" 'Gadis dalam Kotak', yang berisikan kritik terhadap kebijakan pemerintah yang membatasi aktivitas wanita dalam politik-orasinya itu disampaikan dengan bahasa yang sederhana namun cerdas (Nobuhiko 1977: 91-93). Perjuangan Kishida tidak hanya dilakukan melalui tulisan ataupun orasi politik, tetapi ia terjun langsung dalam berbagai aktivitas gerakan.

" Kishida Toshiko dianggap sebagai orator wanita pertama di Jepang.

"Jiyuu-To 'Partai Liberal' merupakan salah satu partai di antara partai partai lain yang baru berdiri setelah pemerintah Meiji berjanji akan membangun suatu parlemen berdasarkan pemilihan umum pada tahun 1889. Janji pemerintah itu dikeluarkan setelah mendapat banyak tekanan dari Jiyuu Minken Undou 'Gerakan Hak dan Kebebasan'.

10 Jiyuu Minken Undou mulai muncul tahun 1874. Gerakan ini dimulai ketika terjadi perdebatan di antara dua kelompok yang berselisih dalam pemerintahan oligarki Meiji mengenai masalah politik luar negeri Jepang terhadap Korea. Fokus masalah Korea ini adalah mengenai pengiriman tentara ke Korea. Namun, keputusan pengiriman tentara ke Korea ditentang oleh para menteri, di antaranya Iwakura Tomomi, Okubo Toshimichi, Kido Koin, dan Itoo Hirobumi menentang Saigo Takamori, Sanjo Sanetomi, Itagaki Taisuke, dan lain-lain. Akhirnya, masalah penyerangan ke Korea dibatalkan. Keputusan ini diprotes oleh orang-orang yang mendukung penyerangan ke Korea. Mereka melepaskan jabatan di pemerintahan dan kembali ke kampung halamannya masing-masing. Dari situ mereka melancarkan protes terhadap pemerintah. Saigo Takamori mengobarkan pemberontakan siniturai-Perang Barat Daya - terbesar pada masanya. Sementara itu, Itagaki dan kawankawanya pada tanggal 17 Januari 1884 mengajukan petisi kepada pemerintah agar segera dibuka parlemen berdasarkan pemilihan umum atau Minsen Giin Setsuritsu Kempakusho. Pengajuan petisi inilah yang merupakan awal dari gerakan hak dan kebebasan di Jepang. Setelah itu, gerakan ini meluas hampir ke seluruh negeri. 
Tulisan-tulisan Kishida mengenai hak kebebasan wanita banyak tersebar dalam "Jiyu no Tomoshibi" 'Obor Kebebasan', sebuah harian milik kelompok Jiyu-To 'Partai Liberal' yang terbit pada tahun 1884. Di balik gerakannya untuk memperjuangkan nasib wanita, ia juga berpendapat bahwa peradaban Barat tidak semuanya dapat diterima begitu saja. Menurutnya, pemerintah harus menyaring dan menerapkan kebijakan yang sesuai dengan tradisi Jepang.

Perempuan perintis lain yang dianggap terbesar pada zamannyazaman Meiji - adalah Fukuda Hideko yang juga dikenal sebagai Kageyama Hideko (1865-1927). Fukuda Hideko banyak mempromosikan hak-hak perempuan melalui gerakan sosialis dan pasifis. Ia lahir di Prefektur Okayama, sebagai putri seorang samurai rendahan Kageyama Katashi, sedangkan ibunya, Umeko, adalah guru sekolah dasar. Setelah lulus dari sekolah dasar, Fukuda Hideko mulai bekerja sebagai asisten guru.

Terkesan dengan orasi mengenai hak-hak wanita yang diberikan oleh Kishida Toshiko, pada tahun 1882 Fukuda Hideko mulai aktif dalam kuliahkuliah wanita di Okayama. Pada tahun 1883, bersama-sama dengan ibunya, ia mendirikan sekolah untuk para gadis yang diberi nama Joukou Gakusha, namun tahun berikutnya sekolah ini ditutup oleh pemerintah prefektur karena diduga guru-gurunya telah melakukan aktivitas politik yang melanggar peraturan pemerintah mengenai rapat umum.

Fukuda memiliki keyakinan politik bahwa mengubah nasib dan peranan kaum perempuan dapat dilakukan jika dia memiliki akses kekuatan politis yang didapatkan dengan cara turut serta berpartisipasi aktif dalam kegiatan politik. Oleh sebab itulah, untuk merealisiasikan apa yang dicita-citakannya, ia turut aktif dalam gerakan Jiyuu Minken 'Gerakan Hak dan Kebebasan'.

Melihat potensi kaum perempuan yang besar dalam memajukan bangsanya, melalui gerakan tersebut Fukuda Hideko menuntut agar pendidikan wanita ditingkatkan, menuntut agar kaum perempuan diberikan hak pilih bersama-sama dengan kaum laki-laki, dan menuntut agar kaum perempuan boleh aktif di dalam penyelenggaraan pemerintahan, pembelaan, dan pembangunan negara. Bandingkan apa yang telah berada di pikiran Fukuda Hideko pada masa itu dengan hasil Beijing Platform for Action dalam Konferensi Keempat Perempuan Sedunia tahun 1995 yang menyatakan, "Without the active participation of women and the incorporation of women's perspective at all levels of decesion-making, the goals of quality, development and peace cannot be achieved" ${ }^{11}$ Pikiran-pikiran yang dikemukakan Fukuda Hideko melampaui apa yang tidak terbayangkan pada masanya.

Pada tahun 1885, karena diduga terlibat dalam kegiatan faksi radikal Jiyuu Minken Undou yang mendukung reformasi di Korea, Fukuda Hideko ditangkap dan dipenjarakan bersama tokoh Jiyuu Minken Undou yang lain, yaitu Ooi Kentaroo yang kelak menjadi suami pertamanya

${ }^{11}$ Konferensi keempat perempuan sedunia yang disponsori oleh PBB pada musim gugur 1995 dihadiri oleh 40.000 pejuang kesetaraan perempuan di kalangan pemerintah, swasta, dan sebagainya. 
Mulai tahun 1903 sampai dengan 1909 Fukuda Hideko mulai terlibat dengan gerakan-gerakan sosialis, menjadi anggota aktif Heminsha 'Partai Proletar', dan pada saat yang sama Fukuda Hideko aktif sebagai editor majalah bulanan majalah perempuan sosialis pertama, Sekai Fujin 'Wanita Dunia' (Joseishi Sogo Kenkyuukai 1982: 138-148). Selama masa itu Fukuda aktif dalam kampanye-kampanye Heiminsha menentang perang JepangRusia (1904-1905), selain aktif dalam gerakan-gerakan revisi terhadap UU Polisi dan Keamanan Umum serta UU Sipil yang sangat diskriminatif terhadap wanita. Aktivitasnya yang lain di luar politik adalah pada tahun 1901 mendirikan sekolah kejuruan untuk gadis-gadis serta mempublikasikan biografinya tahun 1904, Warawa no Hanshoogai 'Separuh Hidupku', dan tahun 1905 Warawa no Omoide 'Kenanganku'. Rekanrekannya pada masa itu juga termasuk tokoh sosialis Kootoku Shuusui, Sakai Toshihiko, Abe Isoo, dan Ishikawa Sanshiroo. Kemudian pada tahun 1906, bekerja sama dengan Tanaka Shoozoo, Fukuda Hideko melakukan kampanye atas nama para korban polusi dalam kecelakaan tambang tembaga Ashio. ${ }^{12}$ Fukuda Hideko aktif dalam menangani masalah ini. Ia mengunjungi Desa Yanaka untuk melakukan dialog dan memberikan penerangan kepada korban mengenai hak-hak mereka dalam masalah tersebut, aktif menggalang dana untuk membantu para petani Desa Yanaka melalui majalah Sekai Fujin, serta menentang upaya pemerintah yang melakukan tindakan penekanan perihal masalah tersebut. Hal tersebut menunjukkan suatu bentuk kesadaran politik Hideko di hadapan rekanrekan sebangsanya.

Kaum perempuan Kristen Jepang juga berusaha melakukan reformasi sosial. Pada tahun 1886 Yajima Kajiko dan Sasaki Toyoju mendirikan organisasi Kyoufuukai yang merupakan cabang organisasi Woman's Christian Temperance Union (WTCU) ${ }^{13}$. Pada awal tahun 1900-an aktivis Kristen Yamuro Kieko dari Bala Keselamatan dan Hayashi Utako bekerja untuk menolong dan merehabilitasi para mantan pelacur.

Hani Motoko dan suaminya, Hani Yoshikazu, pada tahun 1903 menerbitkan majalah wanita yang pertama Katei no Tomo 'Teman Keluarga' yang pada tahun 1908 diubah namanya menjadi Fujin no Tomo 'Teman Wanita'. Melalui majalah itu, Hani Motoko menaruh minat membuat suatu pencerahan di kalangan ibu rumah tangga kelas menengah dan menyumbangkan ide-idenya berdasarkan pandangan masyarakat Kristen untuk perbaikan kehidupan kaum perempuan. Berbeda dengan majalah wanita yang lain, selain berisikan artikel-artikel mengenai kesehatan dan ekonomi rumah tangga, Fujin no Tomo memberikan advis kemungkinan perubahan hubungan keluarga dan kehidupan perempuan yang berkarier.

${ }^{12}$ Peristiwa polusi tambang Asio merupakan dampak masalah polusi lingkungan yang pertama dipersoalkan secara nasional di Jepang. Sebenarnya yang menarik bukan masalah polusi itu sendiri, tetapi justru korupsi, kolusi, dan nepotisme (KKN) antara oknum tertentu yang duduk dalam pemerintahan dan pemilik pertambangan sumber pencemaran.

13 Organisasi Wanita Kristen yang didirikan tahun 1874 di Amerika yang memperjuangkan nilai-nilai moral, misalnya penghapusan minuman keras. 
Berikutnya, setelah Kaisar Meiji wafat di tahun 1912, kekaisaran dipegang oleh Kaisar Taisho sehingga zaman itu disebut sebagai zaman Taisho yang berlangsung mulai tahun 1912-1926. Karakteristik zaman Taisho ditandai dengan "memanasnya" keadaan politik. Pada masa itu pola ideal dari berbagai aliran dan pemikiran politik adalah menyumbangkan ide-ide "demokrasi" dengan berbagai bentuknya, baik yang condong ke kiri maupun kanan, berikut praktik dan gerakangerakannya. Munculnya kabinet partai politik juga baru pada masa ini sehingga banyak kalangan sejarawan Jepang menyebut periode tersebut sebagai periode demokrasi Taisho untuk membedakannya dengan demokrasi rezim Meiji yang dianggap kurang demokratis.

Tokoh feminis yang muncul pada sekitar periode Taisho adalah Hiratsuka Raicho yang memiliki nama asli Hiratsuka Haruko (1886-1971), putri seorang pejabat pemerintah yang pernah melakukan studi di bidang hukum di Eropa. Kuliah bahasa Inggrisnya dan bacaan-bacaan filosofi Barat yang menjadi latar belakang masa remajanya membuatnya sangat dipengaruhi oleh budaya Barat.

Hiratsuka Raicho pertama kali muncul menggemparkan publik ketika diduga akan melakukan bunuh diri bersama penulis Morita Sohei. Insiden bunuh diri itu pada kemudian hari dikenal sebagai Insiden Baien. Baien sendiri adalah judul novel yang ditulis oleh Morita Sohei (Tachibana 1980: 36).

Bersama dengan gadis-gadis muda lain yang belum menikah dari kalangan kelas menengah yang menyukai sastra, pada tahun 1911 Hiratsuka Raicho mendirikan Seitosha 'Masyarakat Stoking Biru' yang bertujuan untuk mengembangkan bakat perempuan. Seitosha merupakan organisasi feminis dan kemunculannya menandai munculnya gerakan feminisme secara formal di Jepang. Sebelumnya memang telah ada beberapa organisasi feminis dan perintis feminis, seperti Kishida Toshiko dan Fukuda Hideko yang mempropagandakan hak pilih wanita demi kebebasan kaum wanita dalam berpolitik dan sebagainya. Tetapi, bagaimanapun, baru Seitosha yang merupakan organisasi yang berjangkauan nasional dan membawa identitas "wanita baru"14 yang sejak pergantian abad telah mulai melakukan penetrasi ke dunia laki-laki dengan menjadi guru, perawat, pegawai, dan artis. Seperti di berbagai negara lainnya, kemajuan pendidikan telah membentuk kepercayaan diri putri-putri dari keluarga kelas menengah. Dapat dikatakan bahwa Seitosha merupakan organisasi borjuis, yang sebagian besar anggotanya adalah kaum perempuan berpendidikan tinggi (Tachibana 1980: 36-37). Seitosha juga menerbitkan majalah wanita Seito 'Stoking Biru' pada tahun yang sama. Pada nomor pertamanya, majalah itu memuat tulisan-tulisan penyair dan penulis wanita, misalnya Yosano Akiko dan Tamura Toshiko. Sebenarnya, pemikiran Seito tidak pernah mencapai reputasi sastra, namun publikasi

\footnotetext{
1+ Seitosha didirikan menjelang berakhirnya zaman Meiji (1912) sehingga untuk menyambut zaman yang baru, para tokohnya mengidentifikasikan dirinya sebagai atarashii onna, 'wanita baru' yang berbeda dengan perempuan pada masa sebelumnya.
} 
puisi. Yosano Akiko pada nomor perdananya membuatnya harus diperhitungkan pada masa itu. Di dalam puisinya yang berjudul Sozorogoto ‘Pembicaraan yang Menyimpang' pada tahun 1911, Yosano Akiko menulis sebagai berikut.

\footnotetext{
"This is the day mountains shake"

I announce it but no one believes

The mountains were just asleep in olden day

All those mountains were aflame, shaking.

That You don't have to believe,

That all women who were asleep are now awake shaking"

(Morita 1994: 90)
}

Dengan dan melalui puisinya di atas, Yosano Akiko telah mengungkapkan pandangan pribadinya terhadap nasib kaum perempuan dan meramalkan kebangkitan kaum perempuan. The mountains were just asleep in olden day, All those mountaisn were aflame, shaking merupakan gambaran bahwa perempuan yang dahulu tertidur kini telah bangun dan bergolak

Lebih jauh lagi, kepedulian Yosano Akiko terhadap nasib kaum perempuan dapat dilihat dalam tulisannya yang berjudul "Bosei Henjun o Haishu" 'Pandangan Mengenai Ibu yang Dilindungi' (1916) yang berisikan jawaban Yosano Akiko terhadap kritik Ellen Kay mengenai cinta dan pernikahan. Dalam tulisan tersebut, Yosano Akiko menekankan bahwa pemerintah tidak perlu memberikan bantuan dana secara berlebihan untuk kesehatan kaum ibu apabila kaum perempuan tidak tergantung secara finansial pada suaminya. Tulisannya itu merupakan dorongan terhadap kaum perempuan untuk mandiri. Pandangannya mengenai kemandirian kaum perempuan diulangi lagi dalam tulisannya "Hiratsuka, Yamakawa, Yamada no Sanjushi ni Kotau" 'Jawaban terhadap Tiga Perempuan Hiratsuka, Yamakawa, dan Yamada' (1918). Dalam tulisan itu terungkap ketajaman pemikirannya tentang ketidakberdayaan kaum perempuan dan statusnya yang tersubordinasi dan bagaimana menanggulanginya. Ia memiliki keyakinan bahwa kaum perempuan perlu diberdayakan secara ekonomis sehingga tidak tergantung pada pihak lain. Kedudukan kaum perempuan yang inferior dan tidak bebas disebabkan antara lain tidak adanya kekuatan perempuan secara ekonomis, sosial, dan politis yang diperlukan untuk bertahan hidup dalam masyarakat yang sedang berubah dari masyarakat agraris menuju masyarakat industrial yang kapitalistik.

Bahkan, Yosano Akiko banyak menyerang konsep ryousaikenbo 'istri yang baik, ibu yang bijaksana' sebagai filosofi yang dianggapnya tidak cocok digunakan sebagai dasar bagi pendidikan perempuan. Menurutnya, istri yang baik adalah setara dengan gundik, sedangkan ibu yang bijaksana adalah ibu yang tidak menggunakan pikirannya. Lebih jauh menurut Yosano Akiko, pendidikan semacam itu hanya membuat kaum perempuan, terutama kaum perempuan kelas menengah, terbuai dalam cita-cita untuk menjadi pengantin perempuan saja. Yosano Akiko mendorong agar kaum perempuan dapat mandiri baik secara spiritual maupun secara materi sehingga mampu bekerja sama dengan kaum laki- 
laki. Selain itu, Yosano Akiko juga mendorong kaum perempuan lulusan dari pelbagai institusi pendidikan agar berani mengungkapkan pikiran dan keyakinan yang mereka miliki di depan publik. Komentar dan tulisan Yosano sebagian besar mengungkapkan kepeduliannya kepada nasib kaumnya. Ia menginginkan kaum perempuan Jepang maju dan memiliki hak yang sama dengan kaum laki-laki.

Pada awalnya, dalam organisasi Seitosha, kaum perempuan yang tergabung sebagai anggotanya hanya melakukan aktivitas utama yang berhubungan dengan intelektual dan sastra. Namun, tulisan-tulisan mereka dalam majalah Seito memperlihatkan evolusi dari sastra ke arah keprihatinan terhadap permasalahan sosial dan pemikiran feminis yang menggemparkan pada masanya. Keberanian Hiratsuka Raicho dalam tulisannya di Seito didukung oleh rekannya sesama editor, Itoo Noe, yang belakangan terbunuh karena aktivitas anarkisnya.

Hiratsuka Raicho juga mengeluarkan beberapa manifesto dalam bentuk prosa dan puisi di antaranya yang terkenal yang antara lain berbunyi, "Wanita pertama adalah matahari dan merupakan manusia mulia". Terjemahan kutipan lengkapnya adalah "Pada zaman primitif perempuan adalah matahari dan merupakan manusia yang mulia. Sekarang perempuan yang telah berubah menjadi bulan yang pucat harus bersinar kembali seperti sinar matahari di zaman primitif" (Takamure 1980: 278279).0Manifesto itu mengekspresikan keadaan perempuan yang pada umumnya hidupnya tergantung pada kaum laki-laki, bahkan dalam beberapa kasus digambarkan seperti bulan yang sinarnya tergantung pada matahari. Sekarang, di era yang baru - era Taisho- Hiratsuka Raicho dan kawan-kawannya memperjuangkan penghapusan keadaan itu.

Melalui manifestonya, Hiratsuka Raicho memproklamasikan akan bangkitnya kesadaran diri kaum perempuan, seperti yang tergambarkan dari beberapa ratus kaum perempuan yang tergabung sebagai anggota Seitosha serta aktif terlibat dalam segala programnya. Ceramah feminisme yang diadakan organisasi ini pada bulan Februari 1913 dihadiri oleh hampir seluruh anggota Seitosha dan menghadirkan sejumlah penulis pria terkenal sebagai pembicara, antara lain Ikuta Choukou, Iwano Houmei, dan Baba Kochou. Pengaruh terbesar bagi pemikiran-pemikiran Hiratsuka datang dari tokoh feminis Swedia, Helen Key (1849-1926). Akhirnya, karena aktivitasnya, organisasi ini dibubarkan pada tahun 1916.

Selanjutnya, bersama rekan-rekannya, Ichikawa Fusae dan Oku Mumeo, Hiratsuka Raicho kemudian mendirikan Shin Fujin Kyokai 'Asosiasi Wanita Baru' pada tahun 1920. Shin Fujin Kyokai merupakan organisasi wanita pertama dengan jangkauan nasional yang memperjuangkan hak-hak wanita. Di bawah bendera organisasi itu, Hiratsuka Raicho berjuang melakukan reformasi sosial dalam hal hak-hak politik kaum perempuan, kesetaraan antara relasi laki-laki dan perempuan, perlindungan kaum ibu dan anak, serta legalitas posisi kaum perempuan Jepang. Menurut Takamure Itsue, melalui tulisan-tulisannya, Hiratsuka Raicho berusaha memberikan kesadaran kepada pemerintah dan masyarakat tentang nasib 
pekerja perempuan yang menyedihkan di pabrik korek api. Mereka harus bekerja untuk membantu keluarga dengan kondisi kurang gizi dan tidak dapat mengenyam pendidikan yang lebih baik (Takamure 1980: 268 -270).

Berkat perjuangan Shin-Fujin Kyokai, akhirnya pada tahun 1922 pemerintah melakukan amandemen terhadap Chian Keisatsu Hou'UU Polisi dan Keamanan Umum' yang dikeluarkan tahun 1886. Capaian organisasi Shin-Fujin Kyokai merupakan sukses besar gerakan wanita pada umumnya. Amandemen terhadap Chian Keisatsu Hou berarti diakuinya legalitas kaum wanita untuk berpartisipasi di dalam kegiatan politik dalam berbagai tingkatan. Namun, karena kesulitan internal dan tekanan pemerintah, Shin Fujin Kyokai dibubarkan dalam tahun 1922. Meskipun demikian, perjuangan organisasi ini telah berhasil menekan pemerintah untuk mencabut larangan aktivitas kaum wanita berpolitik.

Sementara itu, berkat kesempatan menempuh pendidikan yang lebih baik, golongan menengah di perkotaan melahirkan banyak penulis dan sastrawan andal. Salah seorang di antaranya adalah penyair feminis Yosano Akiko (1878-1942), yang setelah menyelesaikan pelajarannya dari sekolah gadis di Sakai pada tahun 1895, mulai menyumbangkan puisinya yang terkenal di jurnal-jurnal puisi lokal.

Ketika Yosano Tekkan (Hiroshi) memublikasikan terbitan bulanannya, Myojo 'Bintang Terang', Yosano Akiko menjadi salah seorang kontributornya. Pertemuan keduanya pada tahun 1900 diakhiri dengan perkawinan mereka setahun kemudian. Namun, Yosano Tekkan tetap berhubungan dengan wanita lain, baik dengan mantan istrinya, Takino, maupun dengan teman Yosano Akiko sendiri, yaitu penyair Yamakawa Tomiko. Pada tahun 1901 terbit kumpulan puisi Yosano Akiko dalam bentuk tanka ${ }^{15}$ yang kelak terkenal sebagai maestronya, Midaregami 'Rambut yang Terurai', yang berisi kurang lebih 400 puisi-puisi romantis dan sensual. Tamure Itsue juga menulis bahwa syair-syair yang ditulis Yosano Akiko sebagian menggambarkan cinta kasih di antara suami-istri yang menikah bukan karena perjodohan. Tulisannya juga memuat tentang cinta suami yang hanya berpusat kepada istri, bukan kepada wanita simpanan atau wanita penghibur (Lawanda 1996: 30).

Di dalam puisinya yang lain, Yosano Akiko menyuarakan kesedihannya terhadap perasaan wanita yang tertekan dalam kehidupan perkawinan. Pemikiran tentang cinta kasih yang menjadi landasan perkawinan yang muncul saat itu mempengaruhi pemikiran wanita terhadap suami-suami yang memiliki wanita simpanan (Lawanda 1996: 29). Pemikiran Yosano Akiko mengenai kehidupan perkawinan bisa jadi diperoleh dari pengalaman pribadinya, dari hidup perkawinannya seperti yang sudah dijelaskan dalam tulisan di atas.

Yosano Akiko banyak menulis dan memberikan kuliah publik mengenai berbagai masalah sosial, termasuk di dalamnya pendidikan kaum perempuan dan hak pilih perempuan. Gerakan perempuan yang dilakukan

${ }^{15}$ Puisi pendek khas Jepang. 
dan orasi yang dikumandangkan kaum perempuan di depan umum bertujuan menegakan hak kemanusiaan. Berbagai organisasi perempuan dibentuk untuk mengatur dan menyampaikan aspirasi kaum perempuan.

Jelas di sini bahwa apa yang telah ditulis Yosano memperlihatkan kepeduliannya terhadap nasib kaumnya, kaum perempuan. Ia menginginkan kaum perempuan maju dan memiliki hak yang sama dengan kaum pria. ${ }^{16}$ Pemikiran-pemikiran Yosano, mengenai persamaan hak antara kaum perempuan dan kaum laki-laki, sangat memberikan pengaruh besar bagi gerakan perempuan pada masa itu yang dimotori oleh organisasi Seitosha

Sementara itu, akibat revolusi industri yang dilakukan pada awal zaman Meiji, muncul masalah-masalah yang berkaitan dengan perburuhan, misalnya kondisi kerja yang buruk di pabrik, jam kerja yang panjang, upah yang rendah, masalah buruh anak-anak, diskriminasi di lapangan pekerjaan, dan prostitusi. Sejak awal tahun 1886 sudah mulai muncul pemogokan buruh yang dilakukan oleh kaum perempuan dan pada tahun 1919 seksi perempuan dari organisasi buruh Yuaikai mensponsori rapat umum buruh tekstil untuk mendukung resolusi International Labor Organization (ILO) mengenai kondisi buruk buruh perempuan Jepang.

Pada bulan April 1921 kaum perempuan sosialis, seperti Yamakawa Kikue, Itoo Noe, Kutsumi Fusako, dan Sakai Magara membentuk organisasi Sekirankai 'Masyarakat Ombak Merah', yang merupakan organisasi pembantu dari Nihon Shakai Shugi Doumei 'Liga Sosialis Jepang'. Sekirankai merupakan organisasi yang berhubungan aktif dengan organisasi sayap kiri. Kelompok ini bercita-cita menghapuskan kapitalisme yang dianggap sebagai penyebab tekanan terhadap kaum perempuan. Secara spesifik kelompok ini memperjuangkan penerimaan upah yang sama, kesejahteraan $\mathrm{ibu}$, dan penghapusan prostitusi. Namun perkumpulan ini dan perkumpulan sosialis lain dilarang oleh penguasa pada masa itu, sejalan dengan kecurigaan pemerintah dengan organisasi-organisasi kiri.

Selanjutnya, pada awal tahun 1924 - pada saat gerakan-gerakan feminis sedang surut-salah seorang pendiri Shin Fujin-Kai yang telah dibubarkan, yaitu Ichikawa Fusae, kembali ke Jepang setelah menyelesaikan studinya selama dua setengah tahun di Amerika. Pada waktu itu di Amerika sedang marak gerakan sufragis - suatu gerakan yang menuntut agar wanita memiliki hak suara agar kaum wanita mempunyai wakil-wakilnya yang dapat menyuarakan aspirasi mereka (Nurliana, 1996: 18-20).

Terinspirasi oleh aktivitas kaum feminis yang diamatinya di Amerika serta hubungannya dengan Alice Paul dan National Women's Partynya ${ }^{17}$, Ichikawa mencoba membentuk organisasi baru yang kelak dikenal sebagai Fusen Kakutoku Doumei 'Liga Hak Pilih Wanita' yang menjadi organisasi sentral dari gerakan feminisme nonsosialis. Selama 16 tahun berikutnya,

${ }^{16}$ Kehidupan Akiko sendiri sebagai seorang ibu yang mandiri dengan 11 orang anak dinilai berhasil. Sebagian besar anak-anaknya kelak menjadi orang penting. Dia dianggap berhasil menjadi istri yang setia kepada suami sekaligus seorang wanita karier yang berhasil. 
Ichikawa Fusae berjuang membujuk politisi-politisi liberal untuk menggolkan UU yang dapat memberikan hak pilih bagi kaum perempuan. ${ }^{18}$ Namun dalam sidang-sidang Diet, usahanya selalu mendapat tantangan dari partai politik sayap kiri yang juga memiliki organisasi perempuan. Kaum perempuan sayap kiri kerap mengkritik usaha-usaha yang dilakukan oleh Ichikawa Fusae yang dikatakan hanya berkisar pada isu hak pilih perempuan saja dibandingkan dengan banyak masalah lain yang harus dihadapi kaum perempuan.

Namun, bersamaan dengan diadakannya persiapan perang Pasifik dan atas dasar komitmen nasional, ada kecenderungan melunaknya gerakangerakan liberal. Pada akhirnya Fusen Kakutoku Doomei dibubarkan pada tahun 1940. Selain memperjuangkan hak pilih perempuan melalui organisasinya, Ichikawa Fusae banyak mendorong ibu rumah tangga untuk lebih aktif dalam permasalahan yang timbul di komunitas lokal. Di masa Perang Dunia, Ichikawa Fusae turut menggugah minat wanita dan memobilisasi kaum wanita untuk menghadapi masalah-masalah yang berkaitan dengan perang, misalnya masalah kelangkaan bahan makanan dan ketiadaan laki-laki dalam kehidupan rumah tangga. Akan tetapi, karena aktivitasnya dalam Nihon Genron Houkoku 'Asosiasi Pidato Patriotik Jepang' yang disponsori oleh pemerintah Jepang, di bawah pemerintah pendudukan sekutu aktivitasnya politiknya dibatasi.

Selain tidak cukup dukungan dari gerakan-gerakan proletariat secara keseluruhan, para "feminis borjuis" juga menghadapi permusuhan terbuka dari kaum perempuan yang berorentasi tradisional yang sulit diajak untuk bekerja sama dalam masalah hak pilih. Hanya beberapa di antara kaum perempuan yang berorientasi tradisional mampu memahami peranannya yang lain dibandingkan sekadar hanya mempraktikkan pola ideal peranan kaum perempuan yang telah disebutkan sebelumnya (ryousaikenbo).

Keluarga berencana adalah isu lain yang didukung oleh para perempuan pemimpin Jepang yang terinspirasi oleh pemikiran neo-Malthusian yang masuk ke Jepang pada pergantian abad. Pada awal zaman Meiji, keluarga berencana, baik itu berupa infanticide atau aborsi, dinyatakan sebagai suatu praktik yang dilarang - hal ini sejalan dengan semangat prinsip-prinsip ekonomi Barat pada masa itu. Dengan demikian, pertumbuhan ekonomi tinggi yang diikuti dengan meledaknya angka kelahiran telah mendorong pertumbuhan penduduk Jepang yang cukup besar 55 juta jiwa pada tahun 1920. Namun, setelah Perang Dunia I (1914-1918) yang diikuti dengan depresi ekonomi, pada masa sulit, sejalan dengan munculnya gerakangerakan buruh, ada usaha untuk menyokong diadakannya gerakan

\footnotetext{
${ }^{17}$ Alice Paul adalah tokoh feminis Amerika, yang pada tahun 1912 menjadi Ketua National American Woman Suffrage Association (NAWSA). Ia mengorganisasi kaum perempuan untuk mengadakan unjuk rasa ke ibu kota Washington, D.C. Tujuan demonstrasi itu adalah memopulerkan amandemen tentang hak pilih. Bersamaan waktunya, Presiden Woodrow Wilson akan dilantik sehingga demontrasi itu menarik banyak perhatian. (Nurliana 1996: 22)

${ }^{18}$ Kaum wanita Jepang baru berhasil memiliki hak pilih pada tahun 1946.
} 
keluarga berencana. Gerakan ini pertama-tama dipimpin oleh seorang dokter pria yang terdidik di luar negeri, yaitu Majima Kan (1893-1969). Kemudian, masalah itu diambil alih oleh gerakan perempuan yang menyokong perlindungan terhadap hak kesehatan dan reproduksi ibu.

Pada tahun 1918-an majalah perempuan mulai banyak banyak memuat artikel dan iklan yang berhubungan dengan peralatan dan obat kontrasepsi. Salah seorang aktivis yang mendukung program keluarga berencana adalah Ishimoto Shizue, dan setelah perang, sebagai anggota Diet, dia yang kemudian dikenal sebagai Katoo Shizue tetap aktif mendukung program yang sama.

Dalam tahun 1937 ketika Jepang sedang menghadapi perang di Cina, karena tuntutan bagi pengadaan prajurit baru dan para pekerja untuk mendukung perang, gerakan feminisme dengan isu mengontrol kelahiran ditekan oleh pemerintah. Di bawah pemerintah militeris Jepang menjelang pecahnya perang Jepang-Cina (1937-1945), diterapkan slogan umeyo fuyaseyo 'lahirkanlah anak-anak untuk memperbesar populasi'. Pada masa ini hukum yang diterapkan terhadap siapa pun yang menjalankan praktek keluarga berencana sangat keras.

Sejalan dengan munculnya pemerintah militeris yang konservatif, gerakan perempuan sayap kiri, seperti gerakan sosial demokrat pada umumnya menjadi lemah menghadapi sikap keras pemerintah yang mengklasifikasikan gerakan kiri sebagai "pemikiran berbahaya". Tindakan penekanan yang dilakukan pemerintah dengan penangkapan ratusan aktivis sayap kiri, termasuk aktivis buruh seperti Tanno Setsu, dengan sendirinya mengurangi aktivitas gerakan wanita sayap kiri.

Gerakan-gerakan feminisme terus berlangsung di masa perang. Di antaranya dua organisasi wanita yang cukup besar adalah Dai Nippon Kokuboo Fujin-kai 'Asosiasi Wanita untuk Pertahanan Negara' yang dibentuk pada tahun 1932 tidak lama setelah terjadi insiden Manchuria. Kemudian, pada tahun 1934 dimergerkan dengan kelompok-kelompok yang sejenis yang didirikan atas bantuan pemerintah. Aktivitas utama yang dilakukan organisasi tersebut adalah mengadakan upacara pelepasan prajurit yang pergi ke medan perang, merawat yang terluka, dan menolong para keluarga yang anggotanya gugur di medan perang. Organisasi itu dipimpin oleh Mutoo Nobuko dan pengurus lain yang terdiri atas para istri pejabat militer yang masih berdinas aktif. Pada tahun 1934-1942 diperkirakan anggota yang tergabung di dalamnya berjumlah sekitar $5-7$ juta orang.

Organisasi yang mirip, namun sedikit lebih kecil dari, Dai Nippon Kokuboo Fujin-kai sudah berdiri sejak periode sebelumnya yang sementara kalangan menamainya dengan nama yang terdesan lebih perkasa: Aikoku Fujin-kai 'Asosiasi Wanita Patriotik'. Walaupun pada hakikatnya kedua kelompok ini menjalankan misi dan fungsi yang sama selama perang, yang disebut pertama lebih sukses. Di tahun 1942 atas kebijakan pemerintah, kedua kelompok ini dan satu kelompok lain, yaitu Dai Nippon Rengo Fujin-kai, difusikan menjadi Dai Nippon Fujinkai 'Asosiasi Wanita Jepang Raya'. Dai 
Nippon Fujinkai adalah organisasi nasional yang dibentuk untuk memobilisasi seluruh wanita agar mendukung perang. Organisasi baru ini banyak melakukan proyek yang berkaitan dengan bantuan kepada prajurit dan keluarganya, memberikan latihan perlindungan terhadap serangan udara dan mengumpulkan potongan material. Kegiatan lain adalah mengampanyekan patriotisme dan penghematan. Di masa perang dikatakan hampir semua gadis-gadis yang telah berumur 20 tahun maupun wanita-wanita yang belum menikah berperan aktif sebagai anggota organisasi ini. Organisasi ini dibubarkan pada bulan Juni 1945 dan dihidupkan kembali dengan nama Kokumin Giyuu Sentoukai 'Korps Sukarelawan Rakyat' (Yoshimi 1988: 216-230).

Di masa perang, kaum perempuan muda dimobilisasi sebagai tenaga kerja yang beroperasi di sektor-sektor yang mendukung perang. Namun, kebijakan pemerintah waktu itu terhadap perempuan yang menikah justru sebaliknya: mereka tetap dirumahkan karena lebih berpotensi untuk memproduksi prajurit baru dan tenaga kerja lainnya.

\section{Kesimpulan}

Tulisan ini menunjukkan bahwa, ternyata, tumbuh bangkitnya gerakan feminisme di Jepang berkaitan erat dengan sejarah masyarakat khususnya sejarah kaum perempuan dan tidak dapat dilepaskan dari sejarah perkembangan politik negara tersebut. Selanjutnya dari penelitian ini juga diperoleh data tentang perkembangan sejarah Jepang yang besar pengaruhnya terhadap peran dan kedudukan kaum perempuan. Bila dalam periode kuno kedudukan kaum perempuan relatif setara dan, bahkan dalam beberapa kasus mungkin dapat dikategorikan tinggi, memasuki periode pertengahan dengan munculnya kelas samurai, kedudukan perempuan secara perlahan tetapi pasti terdesak ke dalam posisi inferior. Namun, seiring dengan masuknya pengaruh peradaban Barat dan tuntutan sejarah, muncul tokoh-tokoh yang secara individual ataupun terorganisasi memberikan sumbangan pemikiran bagi munculnya gerakan feminisme.

Timbulnya gerakan feminisme di Jepang bermula dari kesadaran untuk mencari keadilan bagi perempuan yang disertai keyakinan pentingnya perbaikan moral dalam masyarakat. Pada awalnya gerakan feminis dimotori oleh wanita-wanita kelas menengah dari kalangan yang terdidik dengan baik. Pada perkembangan selanjutnya, dalam pasang-surutnya, gerakan feminis dipengaruhi oleh beberapa faktor, antara lain kondisi dan peristiwa politik, pertambahan jumlah kaum perempuan yang berpendidikan, perkembangan industrialisasi berikut masalah-masalah yang berkaitan dengannya, gerakan perbaikan moral dalam masyarakat, serta pengaruh dunia luar, khususnya pengaruh Barat yang dalam kasus Jepang diimplementasikan dalam kebijakan Bunmei Kaika. Faktor lain yang mempengaruhi gerakan feminisme di Jepang adalah kebijakan pemerintah.

Pada umumnya gerakan feminisme sebagai gerakan sosial tidak muncul secara tiba-tiba, tetapi merupakan perkembangan dalam masyarakat yang 
sedang dilanda kecemasan dan ada individu yang menghendaki perubahan dan kemudian tergabung dalam tindakan bersama. Meskipun organisasiorganisasi tersebut bukanlah organisasi politik, keikutsertaan individu dalam organisasi mau tidak mau telah memupuk kesadaran politik.

Dalam rangka mempelajari dan memahami persoalan yang dihadapi kaum wanita di Indonesia, kajian tentang sejarah perempuan dan gerakan feminisme di Jepang besar relevansinya. Lebih-lebih karena negeri kita akan memasuki era industrialisasi yang menyebabkan terjadinya transformasi masyarakat secara besar-besaran. Dampaknya terhadap kaum perempuan sudah tentu cukup besar. Pengalaman historis dari kaum wanita di Jepang dapat digunakan untuk bandingan reflektif bagi pengalaman kita sendiri di Indonesia. Oleh karena itu, penelitian tentang sejarah perempuan dan gerakan feminisme di Jepang yang masih bersifat awal ini perlu ditindaklanjuti dengan penelitian dan pengkajian yang lebih intensif dan komprehensif. Feminisme telah mengubah pandangan dan sikap masyarakat terhadap peran, status, dan kedudukan perempuan, khususnya di Jepang. Gerakan feminisme akan terus berlanjut dan didefinisikan kembali sesuai dengan zamannya dari setiap generasi sesuai dengan permasalahan yang dihadapi oleh masyarakat yang sezaman pada umumnya dan kaum perempuan pada khususnya.

Tokoh-tokoh pembaharu dalam masyarakat dan gerakan feminisme dengan segala daya dan upaya berusaha memperbaiki kehidupan masyarakat, khususnya kaum perempuan berawal dari reformasi pendidikan di awal periode Meiji. Pendidikan telah memberi peranan dan peluang bagi kaum perempuan untuk menuntut ilmu untuk mengekspresikan dirinya. Keadaan ini berlaku baik di Indonesia maupun di Jepang. Kaum perempuan harus dibangkitkan kesadaran untuk dapat mandiri dan proses pemberdayaan harus tetap dilangsungkan terusmenerus di segala sektor kehidupan.

Sekali lagi, pengalaman historis bangsa Jepang patut menjadi cermin yang merefleksi kehidupan manusia Indonesia. Banyak hal positif yang bisa ditiru, namun ada pula hal-hal negatif yang sebaiknya dihindari. Sejarah bagaikan sebuah kaca spion jika seseorang mengendarai kendaraan. Pengendara tidak boleh mengabaikan sama sekali apa yang terlihat dalam kaca spion yang menggambarkan "peristiwa" yang terjadi di belakangnya karena pantulan "peristiwa" itu dapat membantunya memilih arah yang benar, tetapi tentunya pengendara tidak boleh terlalu asyik dengan pantulan gambar dalam kaca spionnya karena sebenarnya tanggung jawabnya adalah menjalankan kendaraan agar tetap maju (Anderson 1998: v)

\section{Daftar Acuan}

Amal, Siti Hidayati (1995), "Beberapa Berperspektif Feminis dalam Menganalisis Permasalahan Wanita" dalam T.O. Ihromi (ed), Kajian Wanita Dalam Pembangunan. Jakarta: Yayasan Obor.

Ansar, Anwar (1999), Peranan Fukuzazua Yukichi dalam Memodernisasikan Pendidikan Jepang pada Zaman Meiji. Jakarta: Maharini Press. 
Fakih, Mansour (1999), Analisis Gender \& Transformasi Sosial. Yogyakarta, Pustaka Pelajar.

Farha, Ciciek (2000), "Feminisme: Gerakan Protes Terhadap Ketidakadilan" dalam Perempuan dan Kekuasaan. Jakarta: Korps PMII Putri.

Hubies, Aida Fitalaya S. (1977), "Feminisme dan Pemberdayaan Perempuan" dalam Membicangkan Feminisme. Bandung: Pustaka Hidayah, 1977

Joseishi Sougou Kenkyuukai (ed.), (1994), Nihon Joseishi 4: Kindai. Tokyo: Tokyo Daigaku Shuppankai.

Lawanda, Ike Iswary (1996), Gerakan-Gerakan untuk Memajukan Emansipasi Wanita di Jepang Zaman Meiji. Laporan Penelitian FSUI, Depok.

Morita, James R. (1994) "Yosano Akiko (1878-1942)" dalam Japanese Women Writers. Bio-Critical Source Book. Ed. Chieko L. Mulhern. London: Greenwood Press,

Murakami, Nobuhiko (1977), Meiji Joseishi: Bunmei Kaika. Tokyo: Kodansha.

_- _ - (1977), Meiji Joseishi: Joken to Ie. Tokyo: Kodansha.

Nurliana, Nana (1995), Sejaralı Wanita dan Fenimisme di Amerika. Laporan Penelitian FSUI, Depok.

Okamura, Masu (1980), Peranan Wanita Jepang (Terj.).Yogyakarta: Gajah Mada University Press.

Sumiarni, Endang (2004), Jender dan Feminisme. Yogyakarta: Wonderful Publising Company.

Tachibana, Mayumi (1980), Nihon no Onna: Donoyouni Onnatachizva Ikitekitanoka. Tokyo. Takamure, Itsue (1980), Josei no Rekishi (ge). Tokyo: Kodansha.

Yoshimi, Kaneko (1988), Nihon Joseishi Nyumon Kouza: Onna to Ie. Tokyo: Dohseisha. 